\title{
INFRA-RED DRYING AND STERILIZATION OF HIGH MOISTURE ROUGH RICE Matouk, M. M. ${ }^{1}$; M. M. EH-Kholy ${ }^{2}$;A T. Mohamed ${ }^{3}$ and ALShaimaa .M. Shabban ${ }^{4}$ 1-Prof. of Agric. Eng. Agric Eng. Dept. Fac. of Agric. Mansoura Univ. 2-Prof\&Head,Div.of Handling and Processing of Agric.Crops,Agric .Eng. Res. Institute. \\ 3-Lecturer of Agric. Eng. Dept., Fac. of Agric., Mansoura University. 4-Post graduate student, Agric. Eng. Dept., Fac. of Agric., Mansoura Univ.
}

\begin{abstract}
A study was carried out to test and evaluate the effect of high-temperature short time Infra-red heating process using a laboratory scale rotary dryer on drying and sterilization of high moisture rough rice and quality changes of the milled rice. The experimental treatments included five different levels of radiation intensity $(0.973$, $1.033,1.093,1.129$ and $\left.1.161 \mathrm{~kW} / \mathrm{m}^{2}\right)$ and two different grain feed rates $(2.5$ and 3 $\mathrm{Kg} /$ patch). Two different drying models [the simple exponential model (Lewis, 1921) and Henderson and Pabis's model (1961)] were also examined for describing the drying data. The obtained results showed that:

1- Rapid moisture removal from rough rice was obvious particularly at higher levels of radiation intensity and lower grain feed rate.

2- Bulk temperature of the heat treated rice samples ranged from 39.1 to $133.3^{\circ} \mathrm{C}$ depending upon the radiation intensity, exposure time and grain feed rate.

3- Both studied models could satisfactorily describe the drying behavior of high moisture rough rice. However, the Lewis's model considered most proper for describing the drying behavior of rough rice due to simplicity of this model in calculations and analysis.

4- The high levels of infra-red radiation intensity reduced the fungal load in high moisture rough rice in an effective manner.

5- A reduction in broken percentage was observed as the radiation intensity decreased and grain feed rate increased.

6 - Infra-red heat-treated rough rice yielded milled rice slightly yellowish in appearance in comparison with the sun dried sample.
\end{abstract}

\section{INTRODUCTION}

Rice is worldwide consumed and its consumers represent one of the most demanding cereal markets with regard to quality aspects. The reason is that most of the rice production in the world is destined to human consumption and rice kernel breakage can constitute a serious problem for rice processing industry.

Egypt has achieved during the last two decades the highest productivity of rice crop in the world. The yield ranging from 3.05tons / fed in 1990 to 4.23 tons / fed in 2006.

In order to reduce the grain moisture content to the safe storage level after harvest, the rough rice is typically dried using convective heated air, which is a slow process because heated air at a relatively low temperature must be used to avoid or minimize lowering the rice milling quality. The 
convective drying process is normally not able to kill the insects and fungi infested rough rice due to the relatively low air temperature. It would be ideal to develop a drying method that can be used for simultaneous drying and disinfestations of harvested rough rice with high milling quality. The developed method should also be used to preserve the grain from physical and chemical changes induced or supported by excess moisture (Abe et al., 1992; Parti, 1993 and El-Kholy and Tharwat, 2008).

Infrared heating for grain drying and conditioning has significant advantages over conventional drying methods. Among these advantages are higher drying rates giving significant energy saving and uniform temperature distribution giving a better quality product. Therefore, it can be used as an effective new method for drying and sterilization of high moisture cereal crops such as rice grain, this method is considered as an energetic advance that can give an increase in drying efficiency, space saving, clean working environment, etc. (Ratti and Mujumdar, 1995).

The present study aims to test and evaluate the use of hightemperature short time infra-red heating technique for drying and sterilization of high moisture rough rice. In addition, the effect of heating treatment on the grain quality and milling potential was also investigated immediately after the drying process.

\section{MATERIALS AND METHODS}

\section{Material}

Freshly harvested rough rice used for the experimental work was a short grain rice variety (Sakha 101) which harvested from the experimental farm of Rice Mechanization Center (R.M.C) at Meet El-Dyba, Kafr El-Sheikh Governorate during 2012 rice harvesting season.

\section{Equipment and Test Procedure}

An experimental scale rotary heating unit with infra-red heaters was used for the experimental work. The dryer consists of a rotary insulated cylinder $(0.8 \mathrm{~m}$ diameter and $0.3 \mathrm{~m}$ long). One side of the rotary cylinder connected to a driving mechanism consists of $0.15 \mathrm{~m}$ diameter steel flange fixed to the side cover of the rotary cylinder and welded to a steel bar riding with a heavy duty ball bearing. A $0.5 \mathrm{kWlow}$ speed motor with different sizes of bullies was used for power supply and speed control of the rotary cylinder. The other side of the rotary cylinder serves as an inlet for rough rice samples through a $0.1 \mathrm{~m}$ diameter center hole. The heat treated rice discharged through a performed removable sector of the cylinder bottom.

For heating and temperature control of the infra-red heating unit, two ceramic infrared heaters $(1 \mathrm{~kW} / \mathrm{each})$ were fixed over two iron blades and assembled into the center iron bar of the rotary cylinder facing the rice surface. The temperature of rice bulk could be raised up and controlled by changing the radiation intensity of the two heaters using an electric circuit with an AC current controlling dimmer. Fig. (1) shows a schematic drawing for the infra-red heating rotary unit. 


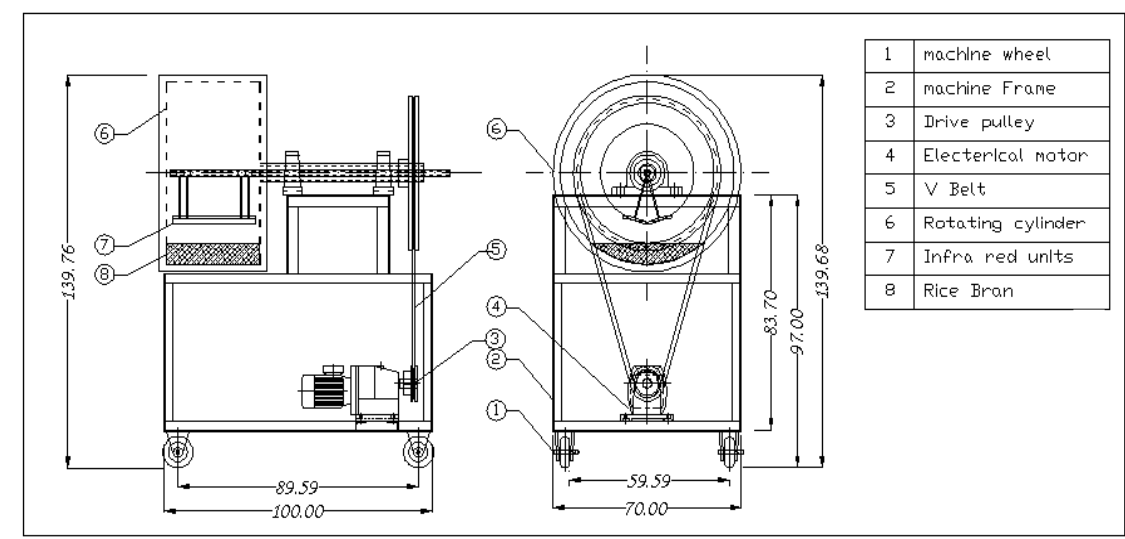

Fig (1): Schematic drawing for the infra-red heating unit

Testing conditions:

\begin{tabular}{|l|c|}
\hline Experimental treatments & Levels of treatments \\
\hline Initial grain moisture content & $21 \pm 1 \%(w . b)$. \\
\hline Radiation intensity & $0.973,1.033,1.093,1.129$ and $1.161 \mathrm{Kw} / \mathrm{m}^{2}$ \\
\hline Grain feed rate & 2.5 and $3 \mathrm{~kg} /$ patch \\
\hline
\end{tabular}

\section{Experimental Measurements}

Determination of rice moisture content

The moisture content of the heat treated rough rice samples was measured by the standard air oven method at $130{ }^{\circ} \mathrm{C}$ for $16 \mathrm{~h}$ as recommended by El-Sahrigi et al. (1999). The oven used for moisture determination is shown in Fig. (2).

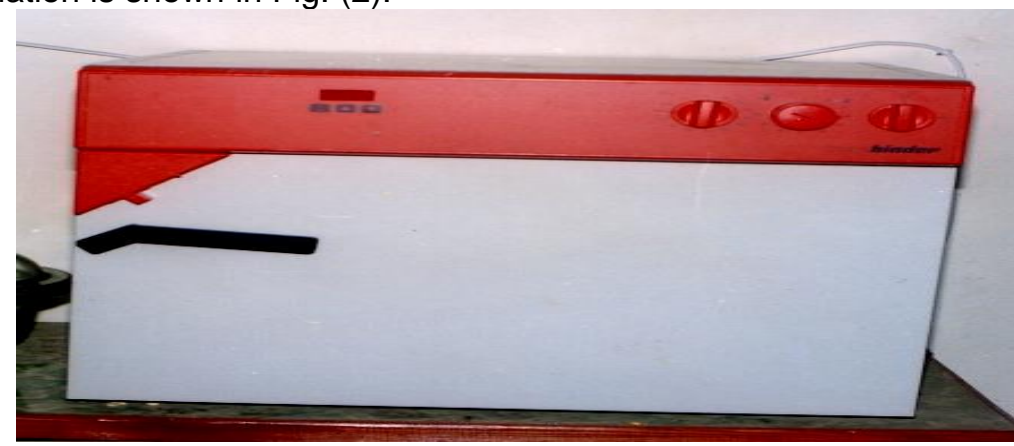

Fig.(2):The electrical oven used for determination of grain moisture content.

Bulk temperature of the heat-treated rough rice:

The temperature of rough rice bulk was immediately measured at the end of each experimental run. The discharged rough rice was received in an insulted glass cylinder and the sensing prop of one point temperature meter model (A.W. SPERRY DM-8600, Taiwan) with rang of 0 to $400^{\circ} \mathrm{C}$ was inserted through the rough rice bulk until reaching a constant reading as shown in Fig. (3). 


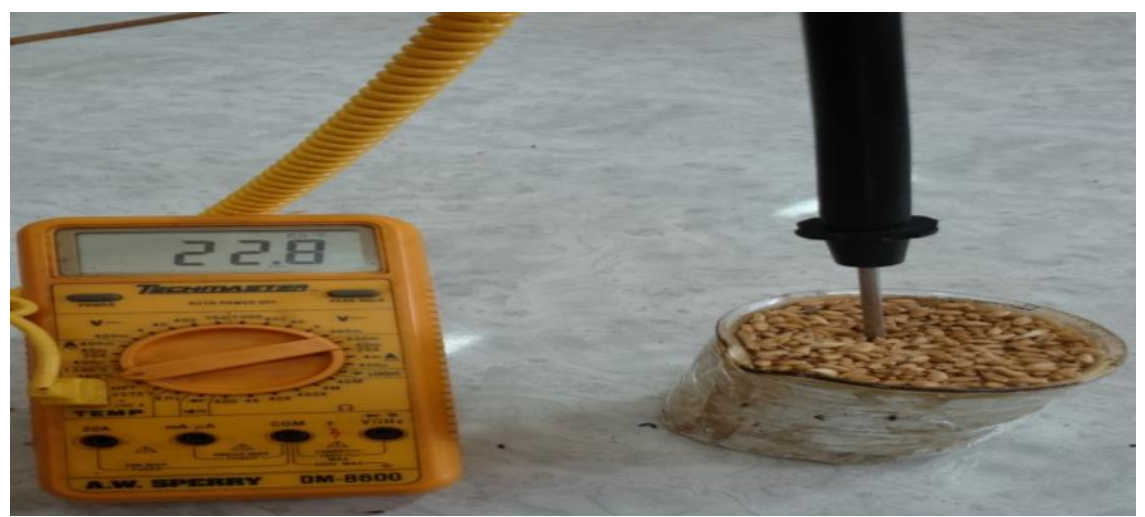

Fig (3): The one point digital temperature meter.

Tests to evaluate grain quality:

The quality evaluation tests for this study may be assessed as follow: 1-Fungal colony count:

The spread plate method recommended by Flannigan, (1977) was used to determine the change in fungal colony count in paddy samples after each experimental run.

\section{2-Grain crack percentage:}

Grain crack percentage was determined according to the method used by (El-Kholy, 1998). For each treatment total of 100 grains were manually dehusked. The resulted brown rice was inspected using the reflection type crack meter, shown in Fig. (4).

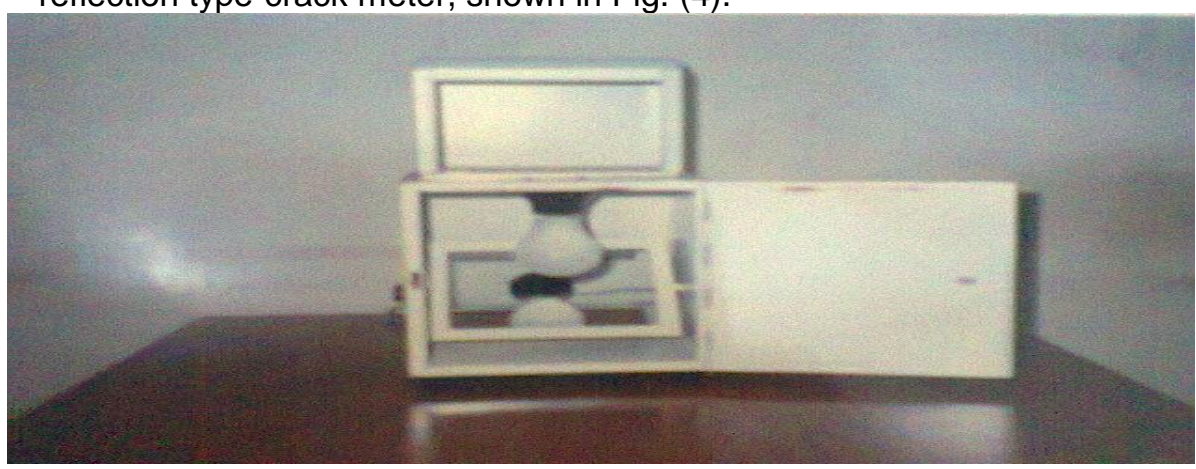

\section{3- Milling tests:}

Fig (4): The reflection type crack meter.

The dried rough rice samples at final moisture content of about $14 \% \pm 1$ (w.b.) were examined for milling tests. The milling quality included percentage of broken rice and whiteness degree. For each test $125 \mathrm{~g}$. of air-dried rough rice samples was passed through a Satake rubber roll husker (model THU35A) with clearance adjusted to give about $90 \%$ brown rice in one pass. The resulting brown rice was poured into the polishing chamber of the Satake rice polisher model (SKD-DBKK) which was operated automatically for $30 \mathrm{sec}$ in each test. For separating head rice from the broken, a laboratory grader 
model (TRG-05) was utilized. Broken percentage of milled rice was calculated as shown in the following equation:

Brocken Kernels $=\frac{\text { weight of brocken kernels }}{\text { total weight of milled rice }} * 100$

The whiteness degree of milled rice samples was measured using a Kett whiteness meter (model C-300) shown in Fig. (5).

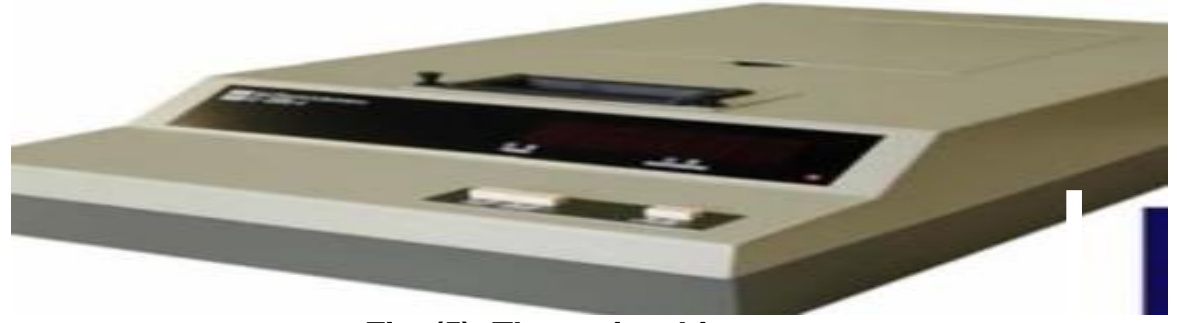

Fig. (5): The grain whiteness meter

Theoretical analysis of the drying process:

To find the most convenient drying models describing the drying behavior of rough rice, two different drying models were examined to fit the drying data, the simple exponential model (Lewis, 1921) and the modified simple exponential model (Henderson and Pabis, 1961).

The equation representing the simple exponential model was represented as follow:

$M R=\frac{M-M_{e}}{M_{o}-M_{e}}=\exp \left(-k_{L} t\right)$

Where:

$M R$ : Moisture ratio, dimensionless

$M$ : Moisture content, \% (d.b).

$M_{e}:$ Equilibrium moisture content, \% (d.b)

$M_{o}$ : Initial moisture content, \% (d.b).

$\boldsymbol{t}$ : Time, min

$k_{L}$ : Drying constant, min-1.

While, the equation representing the Henderson and Pabis's model was written as follow:

$M R=A \exp \left(-k_{H} t\right)$

Where:

$k_{H} \& A$ : Drying constants.

The moisture ratio is usually expressed as:

$$
M R=\frac{M-M_{e}}{M_{o}-M_{e}}
$$


However, there is no information available about the equilibrium moisture content of rough rice in a temperature range of 105 to $145^{\circ} \mathrm{C}$ when the air relative humidity is very low. In this case, the rough rice samples will be bone dried after prolonged heating under such conditions. Therefore, the moisture ratio was approximated by dropping the equilibrium moisture content term and thus the moisture ratio could be simplified to $\left(\boldsymbol{M} / \boldsymbol{M}_{o}\right)$ as mentioned by (El-Kholy, 1998).

\section{RESULTS AND DISCUSSION}

\section{Change in grain moisture content:}

Fig. (6) Illustrates the change in grain moisture contents as related to drying time during the infra-red heating process. It is apparent that the removed moisture increased with the increase of heating time under specific radiation intensity and grain feed rate. Also, the reduction rate of grain moisture content was higher for the grain feed rate of $2.5 \mathrm{Kg} / \mathrm{patch}$ in compression with the feed rate of $3 \mathrm{Kg} /$ patch. This is due to the exposure of more surface area of grain to the infra-red radiation which increased the grain bulk temperature and the corresponding moisture reduction rate. These results are in agreement with the results obtained by (Khir et al, 2011).

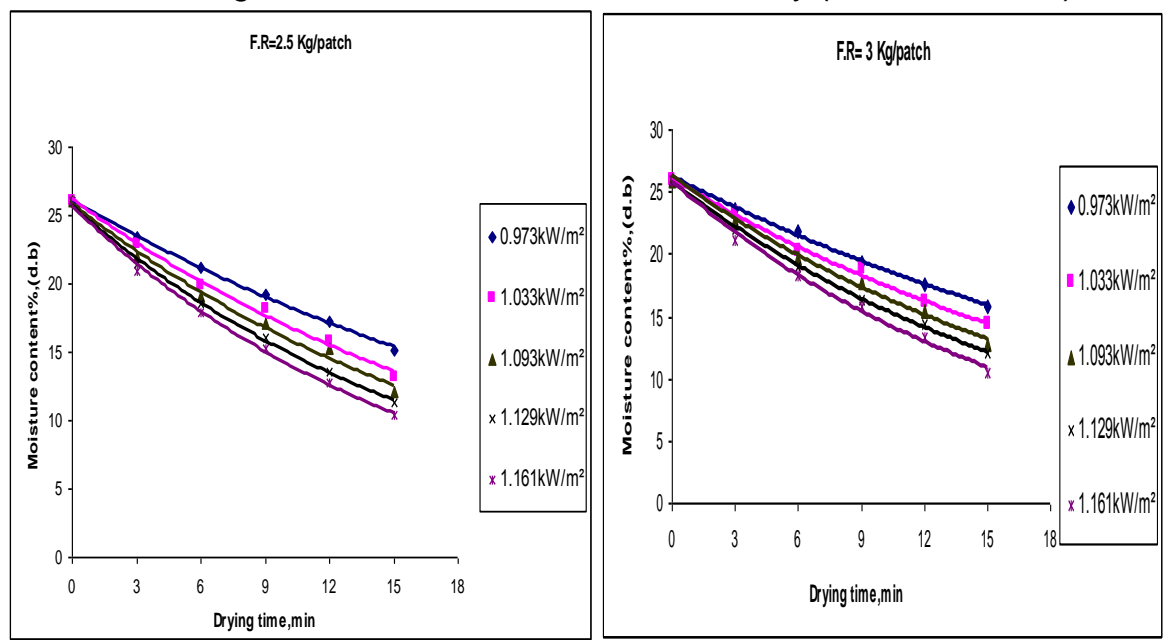

Fig (6): Change in grain moisture content as related to drying time, for different levels of radiation intensity and studied grain feed rates.

\section{Change in grain bulk temperature}

The temperature of heat treated rough rice samples was ranged from 39.1 to $133.3^{\circ} \mathrm{C}$ under the tested conditions. In general, the rice grain temperature increased with the increase of radiation intensity and heating time and it was decreased slightly with the increase of grain feed rate. A typical plot, showing the changes in grain bulk temperature as related to drying time are illustrated in Fig. (7). 

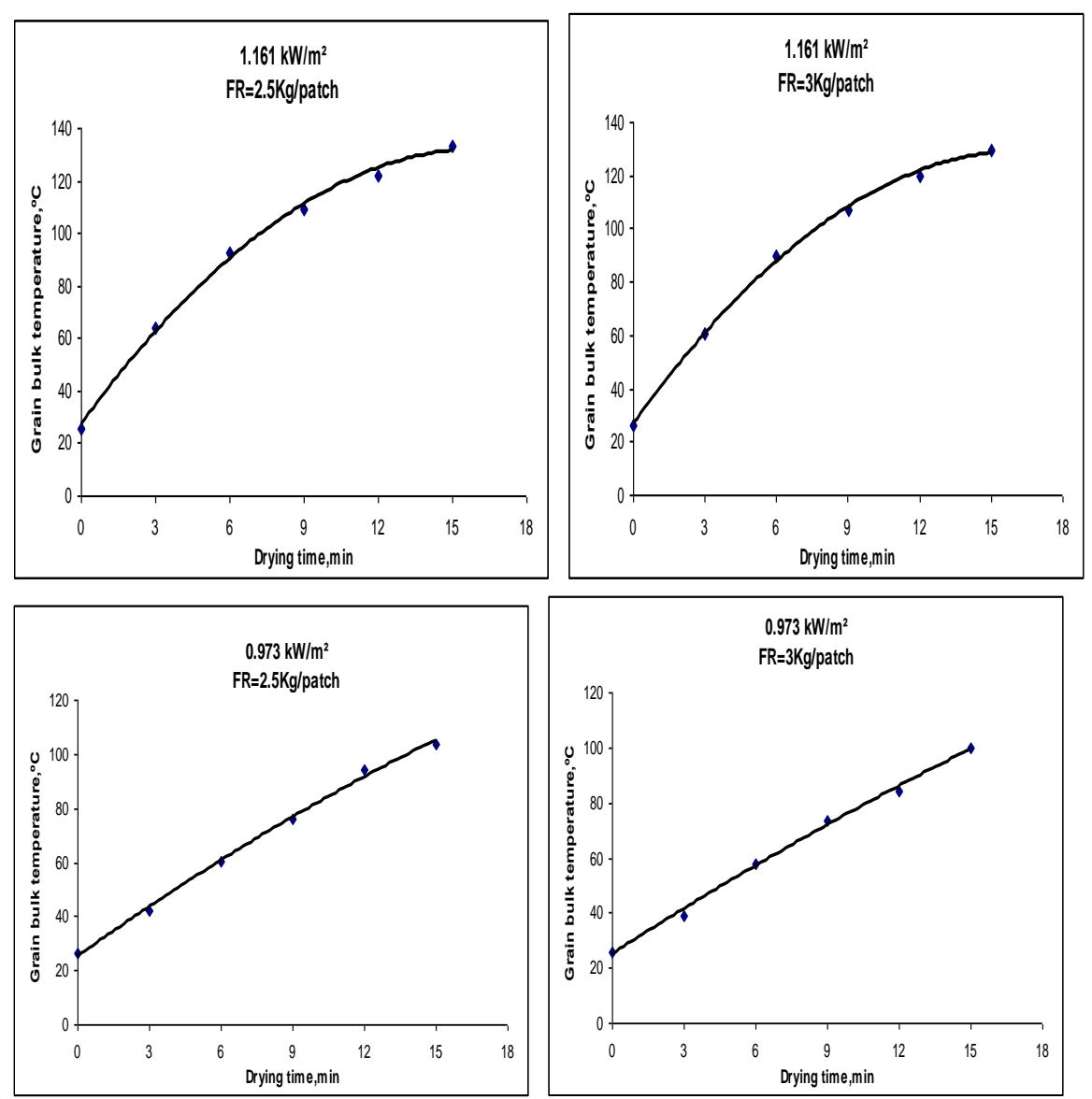

Fig. (7): A typical plot of the change in grain bulk temperature as related to drying time.

Analysis of thin layer drying based on Lewis's model:

The values of drying constant $\left(\mathrm{K}_{\mathrm{L}}\right)$ for Lewis's model (equation 2 ) are listed in table (1).

Table (1): Values of drying constant $\left(\mathrm{K}_{\mathrm{L}}\right)$ for Lewis's model:

\begin{tabular}{|l|c|c|}
\hline \multicolumn{3}{|c|}{ Drying constant (K $\mathrm{K}_{\mathbf{L}}$} \\
\hline \multirow{2}{*}{ Radiation intensity, $\mathbf{k W} / \mathbf{m}^{\mathbf{2}}$} & \multicolumn{2}{|c|}{ Feed rate, $\mathbf{K g} / \mathbf{p a t c h})$} \\
\cline { 2 - 3 } & $\mathbf{2 . 5} \mathbf{K g}$ & $\mathbf{3 K g}$ \\
\hline 0.973 & 0.0349 & 0.0326 \\
\hline 1.033 & 0.0431 & 0.0394 \\
\hline 1.093 & 0.0487 & 0.0452 \\
\hline 1.129 & 0.0549 & 0.0511 \\
\hline 1.161 & 0.0607 & 0.0581 \\
\hline
\end{tabular}

As shown in table (1), the drying constant $\left(\mathrm{K}_{\mathrm{L}}\right)$ increased with the increase of radiation intensity, while it was lower for the grain feed rate of 3 $\mathrm{Kg} /$ patch in comparison with the grain feed rate of $2.5 \mathrm{Kg} /$ patch at all levels of radiation intensity. 
The applicability of Lewis's model in simulating the drying data:

Fig. (8) shows the best fitting for the observed and the calculated values of grain moisture content. The results indicated that, Lewis's model can satisfactorily describe the drying behavior of rough rice during the infrared heating process, as indicated from the high values of coefficient of determination $\left(R^{2}\right)$ and low values of Standard Error (SE) shown in table (2).

Table (2): Values of coefficient of determination $\left(\mathbf{R}^{2}\right)$ and Standard Error (S.E) for Lewis's model.

\begin{tabular}{|c|c|c|c|c|}
\hline \multirow{2}{*}{$\begin{array}{l}\text { Radiation } \\
\text { intensity,kW/m² }\end{array}$} & \multicolumn{2}{|c|}{$2.5 \mathrm{Kg} /$ patch } & \multicolumn{2}{|c|}{$3 \mathrm{Kg} /$ patch } \\
\hline & $\mathbf{R}^{2}$ & S.E & $\mathbf{R}^{2}$ & S.E \\
\hline 0.973 & 0.9997 & 0.1473 & 0.9995 & 0.2161 \\
\hline 1.033 & 0.9986 & 0.3408 & 0.9988 & 0.3153 \\
\hline 1.093 & 0.9973 & 0.4812 & 0.9986 & 0.345 \\
\hline 1.129 & 0.9991 & 0.2763 & 0.9997 & 0.1663 \\
\hline 1.161 & 0.9987 & 0.331 & 0.9977 & 0.4215 \\
\hline
\end{tabular}
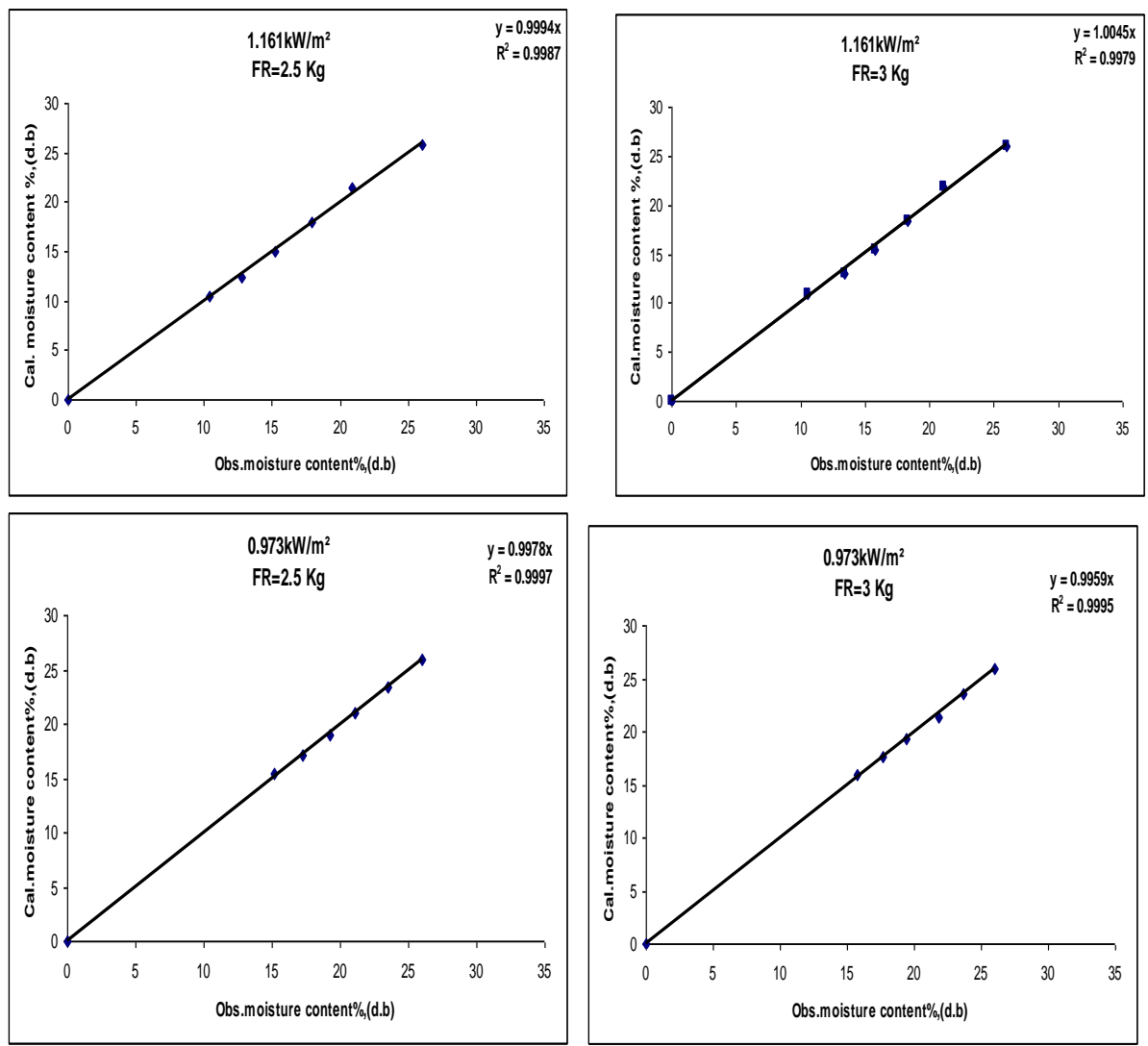

Fig. (8): The observed and calculated moisture content of rough rice using the Lewis's model. 
Analysis of grain drying behavior using Henderson and Pabis's model:

The values of drying constants $\left(K_{H}\right)$ for Henderson and Pabis's model were obtained from the exponential relationship between the grain moisture ratio (MR) and the drying time $(\mathrm{t})$. The slope of this relation represented the constant $\left(\mathrm{K}_{\mathrm{H}}\right)$, while the intercept represented the constant $(\mathrm{A})$. The obtained values of constants ( $\mathrm{K}_{\mathrm{H}}$ and $\left.\mathrm{A}\right)$ are listed in table (3).

Table (3): Values of drying constants $\left(K_{H}\right)$ and $(A)$ for Henderson and pabis's model

\begin{tabular}{|l|c|c|c|c|}
\hline \multirow{2}{*}{ Radiation intensity,kW/m $\mathbf{m}^{2}$} & \multicolumn{4}{|c|}{ Grain feed rate, (Kg/patch) } \\
\cline { 2 - 5 } & \multicolumn{2}{|c|}{$\mathbf{2 . 5} \mathbf{K g}$} & \multicolumn{2}{|c|}{$\mathbf{3 K g}$} \\
\cline { 2 - 5 } & $\mathbf{K} \mathbf{H}_{\mathbf{H}}$ & $\mathbf{A}$ & $\mathbf{K}_{\mathbf{H}}$ & $\mathbf{A}$ \\
\hline 0.973 & 0.0353 & 1.0048 & 0.0334 & 1.0088 \\
\hline 1.033 & 0.0437 & 1.0068 & 0.0396 & 1.0027 \\
\hline 1.093 & 0.0481 & 0.9942 & 0.0459 & 1.0074 \\
\hline 1.129 & 0.0538 & 0.9879 & 0.0504 & 0.9926 \\
\hline 1.161 & 0.0595 & 0.9868 & 0.0575 & 0.9928 \\
\hline
\end{tabular}

The results in table (3) show that, the drying constant $\left(\mathrm{K}_{\mathrm{H}}\right)$ increased with the increase of radiation intensity, while it was decreased with the increase of grain feed rate.

However, the drying constant $(\mathrm{A})$ showed no trend with an average of 0.9961 for the grain feed rate of $2.5 \mathrm{Kg} /$ patch and 1.00086 for the grain feed rate of $3 \mathrm{Kg} /$ patch.

The applicability of Henderson and Pabis's mode in simulating the drying data:

Henderson and Pabis's model could also describe the drying behavior of rough rice as indicated from the high values of coefficient of determination $\left(R^{2}\right)$ and low values of Standard Error (SE) shown in table (4). Fig. (9) also shows the observed and the calculated values of moisture content.

Table(4): Coefficient of determination $\left(R^{2}\right)$ and Standard Error (SE) for Henderson and pabis's model:

\begin{tabular}{|l|c|c|c|c|}
\hline \multirow{2}{*}{ Intenissty,kW/m } & \multicolumn{2}{|c|}{$\mathbf{2 . 5} \mathbf{~ K g}$} & \multicolumn{2}{c|}{$\mathbf{3 ~ K g}$} \\
\cline { 2 - 5 } & $\mathbf{R}^{\mathbf{2}}$ & $\mathbf{S . E}$ & $\mathbf{R}^{\mathbf{2}}$ & $\mathbf{S . E}$ \\
\hline 0.973 & 0.9997 & 0.1515 & 0.9995 & 0.2204 \\
\hline 1.033 & 0.9986 & 0.35 & 0.9988 & 0.317 \\
\hline 1.093 & 0.9974 & 0.4714 & 0.9985 & 0.3573 \\
\hline 1.129 & 0.9991 & 0.2663 & 0.9997 & 0.1629 \\
\hline 1.161 & 0.9988 & 0.3187 & 0.998 & 0.411 \\
\hline
\end{tabular}



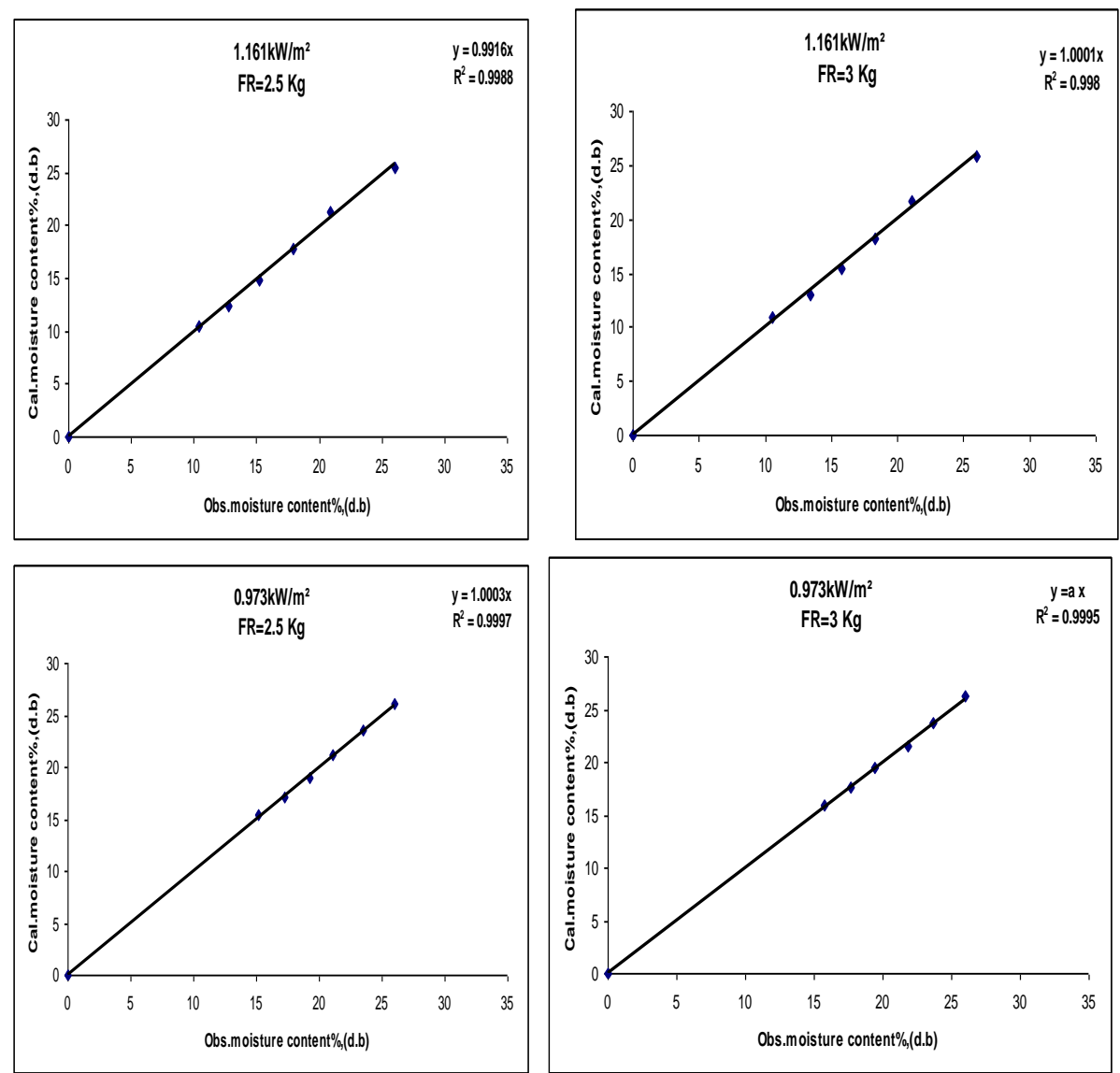

Fig. (9): The observed and calculated moisture content of rough rice using Henderson and Pabis's model.

\section{A comparison between the two studied models:}

In general, both studied models could satisfactorily describe the drying behavior of high moisture rough rice using the infra-red heating process as indicated from the high levels of correlation coefficients $\left(R^{2}\right)$ and low values of S.E shown in tables (2) and (4). However, the Lewis's model could be considered more proper for describing the drying behavior of rough rice due to simplicity of this model in calculations and analysis.

\section{Tests to evaluate grain quality}

\section{Fungi inactivation during infra-red heating process:}

Fig. (10) Illustrates the change in fungal mortality level as related to the radiation intensity for different grain feed rates. It was obviously showed that, the high levels of infrared radiation intensity reduced the fungal load in an effective manner. This effectiveness was obvious as the radiation intensity increased and the grain feed rate decreased. 


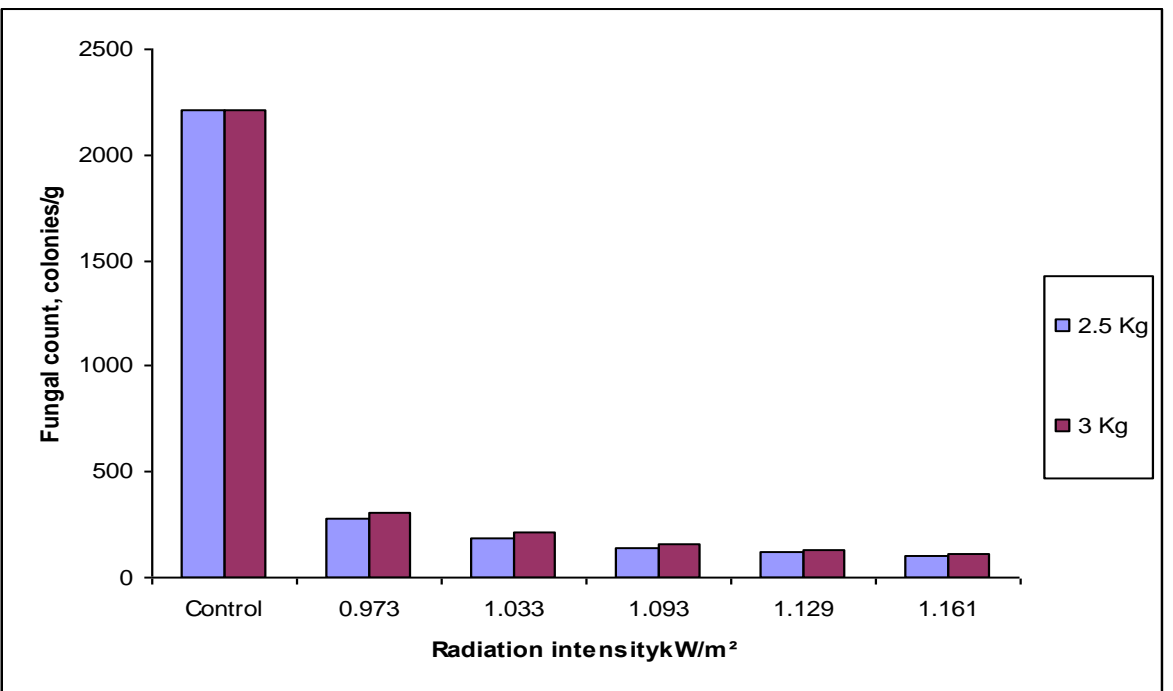

Fig (10): Change in fungal mortality level as related to radiation intensity at different levels of grain feed rates.

\section{Effect of heat treatment on grain crack percentage:}

Fig. (11) Illustrates the effect of heat treatments on grain crack percentage of dried rice. As shown in the figure the heat treated rough rice showed a fluctuation in grain crack percentage depending upon the level of radiation intensity and the grain feed rate.

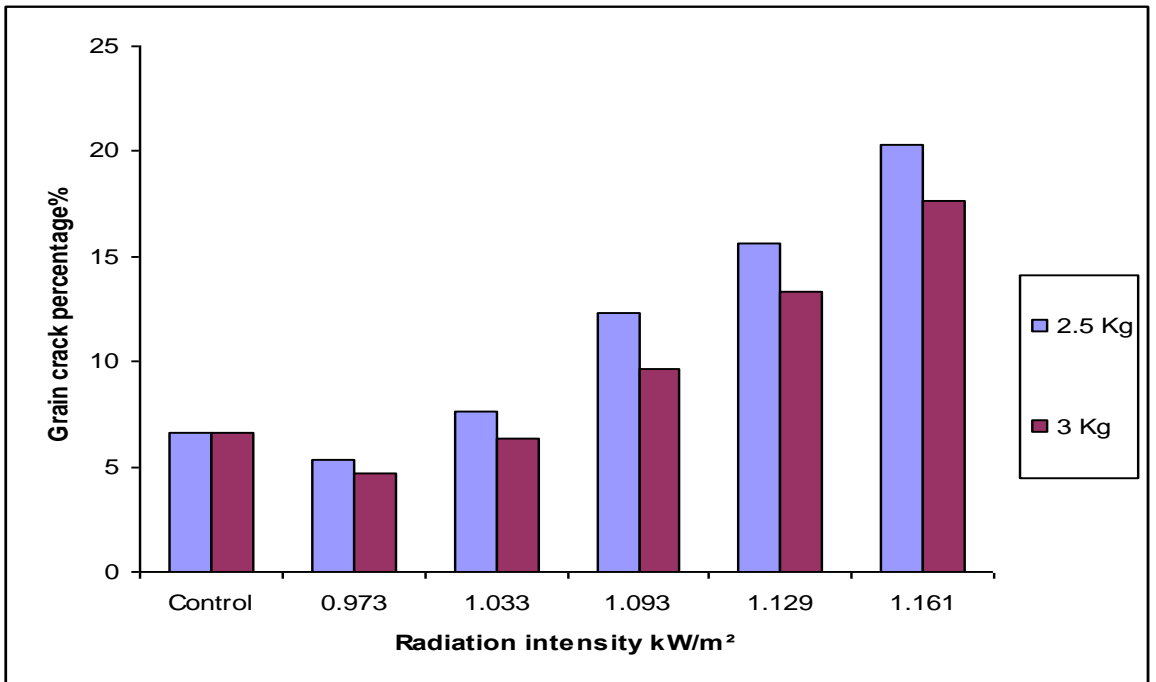

Fig. (11): The change in grain crack percentage as related to radiation intensity for different grain feed rates. 


\section{Effect of heat treatment on grain broken percentage:}

The effect of various heat treatments on grain broken percentage is shown in Fig. (12). As shown in the figure, heat-treated rough rice showed a reduction in broken percentage as the radiation intensity decreased and grain feed rate increased. Similar observations have been confirmed in the past during the high temperature conduction heating of high moisture rough rice by several researchers (Abe et al. 1992 and El-Sahrigi et al. 2000).

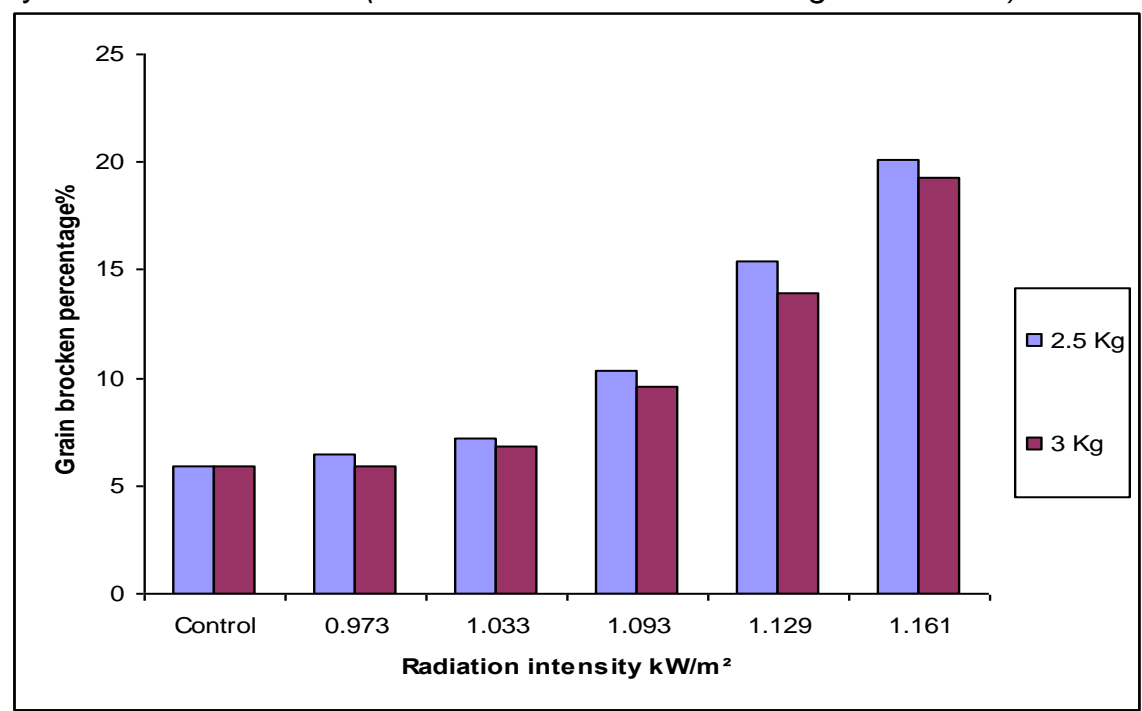

Fig. (12): The change in grain broken percentage as related to the radiation intensity for different grain feed rate.

The reduction in broken percentage of the heat-treated grain exposure to lower level of radiation intensity and higher grain feed rate could be attributed to the lower percentage of cracked kernels which reflected in lower grain broken percentage.

\section{Effect of heat treatment on milled rice whiteness:}

As shown in Fig. (13), Infra-red heat-treated rough rice samples yielded milled rice slightly yellowish in appearance in comparison with the unheated control samples. This change in color could be attributed to the non- enzymatic browning and/or the diffusion of coloring pigments of rice hull and bran to the endosperm caused by exposure of the grain to high levels of radiation intensity. In general, the change in grain color was less severs for milled rice produced from rough rice samples exposed to lower radiation intensity and higher grain feed rate. 


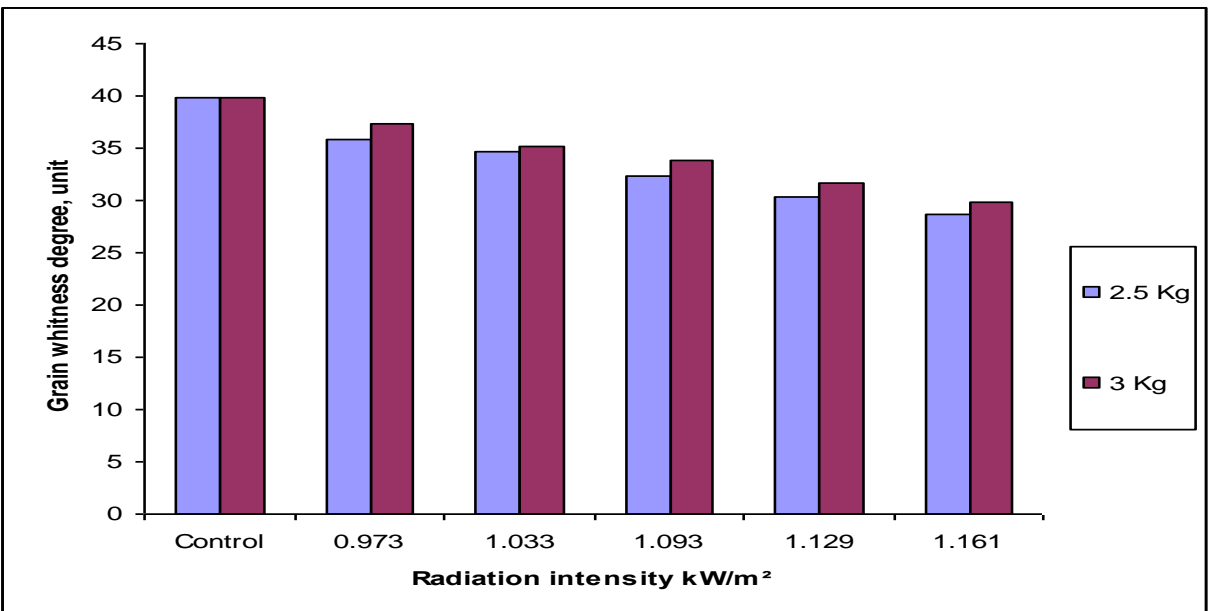

Fig. (13): Whiteness degree of heat treated rough rice during infra-red heating process in comparison with the sun dried sample.

\section{Conclusions}

1- Rapid moisture removal from rough rice was obvious particularly at higher levels of radiation intensity and lower grain feed rate.

2- The temperature of heat treated rice ranged from 39.1 to $133.3 \stackrel{\circ}{\circ}$ depending upon the level of radiation intensity, the exposure time and the fed rate.

3- Both studied models could satisfactorily describe the drying behavior of high moisture rough rice. However, the Lewis's model considered more proper for describing the drying behavior of rough rice due to more simplicity in calculations and analysis.

4- The high levels of infra-red radiation intensity reduced the fungal load in high moisture rough rice in an effective manner.

5- A reduction in broken percentage was observed as the radiation intensity decreased and grain feed rate increased.

6- Infra-red heat-treated rough rice samples yielded milled rice slightly yellowish in appearance in comparison with the unheated control samples.

\section{REFERENCES}

Abe, T., Y. Hikida, C. E. Ofoche and J. Yamashita. (1992). Effect of drying parameters on quality of artificially dried rough rice. Agric. Mech. In Asia, 23(4):42-46.

El-Kholy, M.M. (1998) Conditioning and aeration of high moisture paddy under different storage conditions. Unpublished RHD Thesis, Department of Agri. Eng., Fac.of Agric., Mansoura univ.

El-Kholy, M.M. and A. Tharwat (2008). Accelerated drying and stabilization of canola seeds and oil. Egypt J. of Agric. Sci. Mansoura Univ., 33(11), November. 
EL-Sahirigi, A. F.; A.M. Matouk; H.EL-Abd Alla and M.M. El- holy (1999). Accelerated partial drying and sterilization of high moisture rough rice. Egypt J. Agric. Res., 78(2):977-991.

Flannigan, B. 1977. Enumeration of fungi and assay for ability to degrade structural and components of grain. In Biodeterioration investigation techniques (ed. H. Walters) London, Applied Science Publishers, pp. 185-199.

Henderson, S. M. and S. Pabis, (1961). Grain drying theory. temperature effect on drying coefficient. J. Agric. Engng. Res., 6(31), 169-174.

Khir R.; Z. Pan; A. Salim; R. Bruce and S.M. Radwan (2011). Moisture diffusivity of rough rice under infrared radiation drying. J. of Food Science \& Technology. 44: 1126-1132

Lewis, W.K. (1921). The rate of drying of solid materials J. of Ind. Eng. Chem. 13(5): 427-432.

Parti, M. (1993). Selection of mathematical models for drying grain in thinlayers. J. Ag. Eng. Res.54:339-352.

Ratti, C., and A. S. Mujumdar (1995). Infrared drying. In A. S. Mujumdar

(Vol. Eds.), Handbook of industrial drying (Vol. 1, pp. 567-588). New York: Marcel Dekker, Inc., 742 pp. 
التجفيف والتعقيم لحبوب الارز الثـعيرذات المحتوي الرطوبي المرتفع باستخدام

الاشعة تحت الحمراء

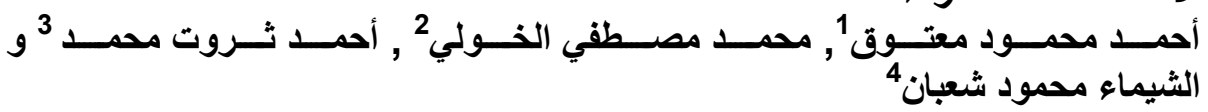

1- أستاذ الهندسة الزراعيةـ قسم الهندسة الزراعيةـ كلية الزراعة - جامعة المنصورة.

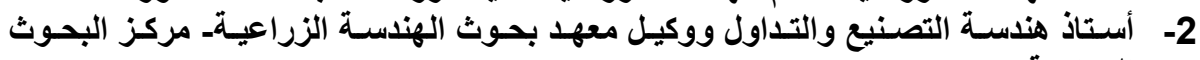

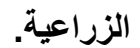

3- مدرس الهندسة الزراعيةـ قسم الهندسة الزراعيةـ كلية الزراعة - جامعة المنصورة. 4- بكالوريوس علوم زراعية (شعبة هندسة زراعية )- كلية الزراعة الزعة - جامعة المنصورة.

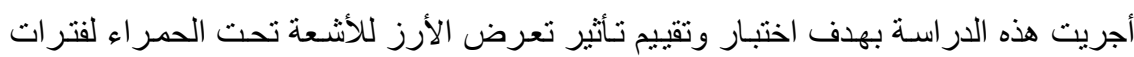

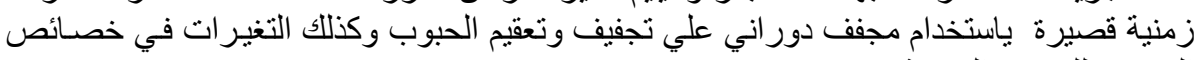
الضرب للحبوب المجفقة.

وقد اشتملت المعاملات التجريبية علي خمسة مستويات مختلفة من درجات الاشعاع (093 (0.973,

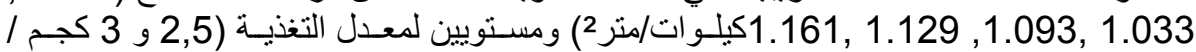

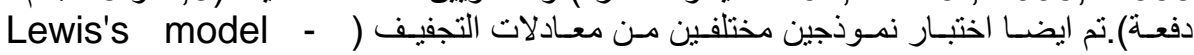
) في وصف منحنيات التجفيف والتنبؤ بـالمحتوي والرطوبي للحبوب اثناء عملية التجفيف.

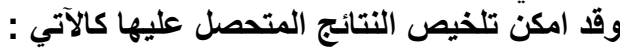
1- إنخفض المحتوي الرطوبي لحبوب الارز الثنعيربطريقة سريعة عند المستويات المرتفعة من شدة الاشعاع و المنخفضة من معدل التربة التغذية.

2- تراوحت درجة حر ارة عينات الأرز الثعير بين 39.1 و 133.3 م معت تحت المعاملات المختلفة

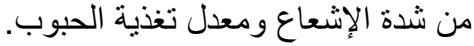

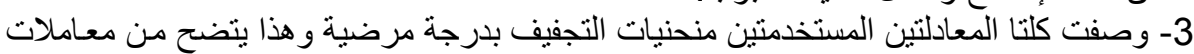

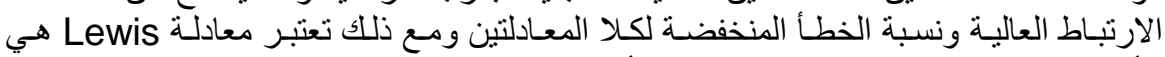

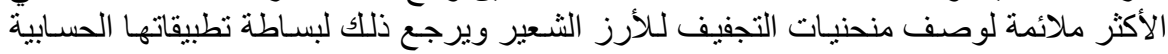

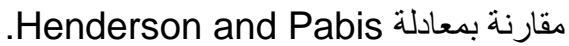
4- تعمل المستويات المرتفعة من شدة الاشعاع علي تخفيض العد الفطري في حبوب الأرز الثعير

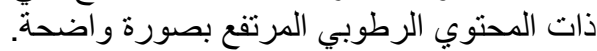
5- انخفضت نسبة الكسر في حبوب الأرز الثنعير بانخفاض مستوي شدة الاشعاع و إرتفاع معدل التغذية. 6- أعطت عينات الأرز الشعير المعالج حر اريا بالاشعة تحت الحمر اء عن حبوب ذات درجة لون أقل بياضا بالمقارنة مع العينة المجففة طبيعيا.

كلية الزراعة - جامعة المنصورة كلية الزراعة - جامعة الاسماعلية
قام بتحكيم البحث

أ.د / ياسر مختار الحديدى اليدى

أ.د / شريف محمد عبد الحق الى 